\title{
COMUNICACÕES
}

\section{Evaluation of culture media for the growth of Bipolaris sorokiniana and Drechslera teres}

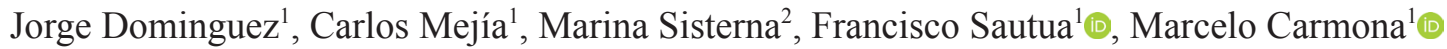

\begin{abstract}
${ }^{1}$ Universidad de Buenos Aires, Facultad de Agronomía, Cátedra de Fitopatología, Av. San Martín 4453. C1417DSE - Buenos Aires - Argentina. ${ }^{2}$ Centro de Investigaciones en Fitopatología (CIDEFI), FCA, Calle 60, Casco Urbano, B1900 La Plata, Buenos Aires-Argentina. Autor para correspondência: Marcelo Carmona (carmonam@agro.uba.ar)

Data de chegada: 21/06/2017. Aceito para publicação em: 16/01/2020.
\end{abstract}

$10.1590 / 0100-5405 / 181689$

\begin{abstract}
Bipolaris and Drechslera are genera of fungi known to cause leaf spots and a variety of symptoms depending on the type of disease and host (2). Wheat and barley crop losses due to leaf spots have been estimated at $15 \%$ to $20 \%$ grain yield reduction (3). Currently, information on the growth and sporulation of these pathogens in different culture media is scarce and outdated. To perform fungicide sensitivity assays, it is important to conduct the tests with a culture medium that maximizes mycelial growth. In general, culture media have been selected in order to maximize sporulation, but information on media that maximize vegetative growth is scarce. Therefore, the objective of the present study was to evaluate the growth of Bipolaris sorokiniana (Sacc.) Schoem. and Drechslera teres (Sacc.) Shoem. in different culture media.
\end{abstract}

A strain of $B$. sorokiniana and a strain of $D$. teres were isolated from barley seeds of the variety Q. Carisma, sampled during the 2015/2016 growing season. A collection of isolates is kept in the University of Buenos Aires, School of Agronomy, Department of Plant Pathology. The used media were: potato carrot agar (PCA, $200 \mathrm{~g}$ potato, $200 \mathrm{~g}$ carrot, $20 \mathrm{~g}$ agar and $1000 \mathrm{ml}$ water), beans agar (BA, $30 \mathrm{~g}$ beans, 20 $\mathrm{g}$ agar and $1000 \mathrm{ml}$ water), rice agar (RA, $30 \mathrm{~g}$ white rice, $20 \mathrm{~g}$ agar and $1000 \mathrm{ml}$ water), potato glucose agar (PGA, $200 \mathrm{~g}$ potato, $20 \mathrm{~g}$ agar and $1000 \mathrm{ml}$ water), potato glucose agar (Britania, $39 \mathrm{~g}$ powder and $1000 \mathrm{ml}$ water), barley leaf agar (BLEA, $200 \mathrm{~g}$ barley leaf extract, $20 \mathrm{~g}$ agar and $1000 \mathrm{ml}$ water), vegetable juice agar (VJA, 1 vegetable stock: 22 g, 20 g agar and $1000 \mathrm{ml}$ water) and carrot agar (CA, 200 $\mathrm{g}$ carrot, $20 \mathrm{~g}$ agar and $1000 \mathrm{ml}$ water). The assay was performed in $90-\mathrm{mm}$ plastic Petri dishes with five replicates. Mycelial discs $(6 \mathrm{~mm}$ diameter) were cut with a number 3 cork borer from 7-day-old stock cultures, inverted, transferred to the media and placed in an incubator under conditions of $12 \mathrm{~h}$ light close to ultraviolet and $12 \mathrm{~h}$ darkness, at $24 \pm 2^{\circ} \mathrm{C}$. Afterwards, the mycelial growth of each pathogen was measured twice with a digital caliper (DIGIMESS, No. 1304I, China) two, four and six days after incubation. Growth rate was estimated based on the formula proposed by Mead et al. (7), cited by Lovato et al. (5): $V=\left(\mathrm{X}_{f}-\mathrm{X}_{i}\right) /\left(\mathrm{T}_{2}-\mathrm{T}_{1}\right)$, where $\mathrm{V}$ is the growth rate $\left(\mathrm{cm} \mathrm{day}^{-1}\right), \mathrm{X}_{f}$ is the final growth $(\mathrm{cm}), \mathrm{X}_{i}$ is the initial growth, $\mathrm{T}_{2}$ is the final time and $\mathrm{T}_{1}$ is the initial time. A completely randomized design with five replicates was performed. Statistical analysis was applied to the results, using One-way ANOVA Tukey's test for comparison of means.

B. sorokiniana had a higher growth rate in RA, PCA, GPA, VJA media, whereas $D$. teres had higher growth in GPA $(\mathrm{p}<0.05)$ (Table 1). The CA medium showed an intermediate behavior for both fungi. Considering the characteristics of the colonies of each strain in the different media, B. sorokiniana in RA showed whitish mycelial growth due to lack of sporulation. In an assay with Fusarium oxysporum in RA, Berton (1) observed that the production of conidia was low, although it was superior to that in wheat flour medium and potato dextrose agar. On the other hand, using GPA (commercial) medium, pink colonies were observed. This finding was unexpected because when commercial GPA is compared to traditional GPA, the differences in color and sporulation were remarkable for B. sorokiniana, which even raised doubts about the isolate. Variation in color and shape has been reported by other authors, e.g., Maraite et al. (6) observed 27 isolates of B. sorokiniana and found different colony colors ranging from white to light pink and reaching dark green. Although sporulation was not quantified in VJA and BLEA media, for D. teres an abundant production of hyaline conidia was recorded, a characteristic that was not observed in other media. According to Hernández \& Rosón (4), the composition of the culture medium can influence the development and the sporulation of fungi because they require sources of carbon, nitrogen, sulfur, iron, sodium and potassium for their metabolism.

In summary, RA, PCA, GPA and VJA for B. sorokiniana, and GPA, CA, PCA, GPA (Commercial), VJA and RA for $D$. teres could be used individually or in combination with other media to achieve the highest growth and sporulation, since other media do not favor the rapid and sustained growth of these pathogens.

Table 1. Average growth rate of $B$. sorokiniana and $D$. teres in different culture media

\begin{tabular}{lcc}
\hline & Colony growth rate $\left(\right.$ cm day $\left.^{-1}\right)$ \\
\hline Medium & B. sorokiniana & D. teres \\
\hline Barley Leaf Extract Agar (BLEA) & $0,55 \mathrm{~d}^{*}$ & $0,21 \mathrm{e}$ \\
Beans Agar (BA) & $0,70 \mathrm{~cd}$ & $0,65 \mathrm{~d}$ \\
Carrot Agar (CA) & $0,81 \mathrm{bc}$ & $0.89 \mathrm{~b}$ \\
Glucose Potato Agar (GPA) & $0,99 \mathrm{ab}$ & $1,06 \mathrm{a}$ \\
Glucose Potato Agar (Commercial) & $0,49 \mathrm{~d}$ & $0,84 \mathrm{bc}$ \\
Potato Carrot Agar (PCA) & $1,09 \mathrm{ab}$ & $0,88 \mathrm{~b}$ \\
Rice Agar (RA) & $1,17 \mathrm{a}$ & $0,78 \mathrm{c}$ \\
Vegetable Juice Agar (VJA) & $0,98 \mathrm{ab}$ & $0,84 \mathrm{bc}$ \\
\hline
\end{tabular}

*Values followed by different letters in a column are statistically different at $\mathrm{p}$ $<0.05$ (Tukey's test) 


\section{REFERENCES}

1. Berton, O. Etiologia da mancha em reboleira da soja (Glycine max (L.) Memil) . 1981. 117 f. Tese (Mestrado em Fitotecnia) - Faculdade de Agronomia, Universidade Federal do Rio Grande do Sul, Porto Alegre.

2. Carmona, M.; Reis, E. M. Patología de semillas en trigo y cebada: detección, epidemiología y manejo. 1. ed. Buenos Aires: BASF, 2019. 152 p.

3. Carmona, M.; Sautua, F. Manejo químico de las enfermedades del cultivo de cebada cervecera en Argentina. In: Kiehr, M.; Wehrhahne, L.; Daddario, J.; Storm, A.; Delhey, R. (ed.). Enfermedades de cebada en Argentina: diagnóstico y manejo. 1. ed. Tres Arroyos: Centro Regional de Ingenieros Agrónomos de Tres Arroyos, 2016. p. 95-115.
4. Hernández, A.; Roson, C. Evaluación del crecimiento y esporulación de Aschersonia aleyrodis (Webber) en medios de cultivo convencionales. Fitosanidad, La Habana, v. 9, p. 61-63, 2005.

5. Lovato, A.; Gutiérrez, S.; Carmona, M. Evaluación de medios de cultivos en el crecimiento de Alternaria padwickii. Fitosanidad, La Habana, v. 19, p. 69-71, 2015.

6. Maraite, H.; Zinno, D.; Longree, H.; Daumerie. V.; Duveiller, E. Fungi associated with foliar blight of wheat in warmer areas. In: International Workshop on Helminthosporium Diseases of Wheat: Spot blotch and Tan spot, 1997, El Batán. Proceedings. El Batán: CIMMYT, 1998. p. 293-300.

7. Mead, G.; Hudson, M.; Hinton, M. Microbiological survey of five poultry processing plants in the UK. British Poultry Science, Chester, v. 34, p. 497-503, 1993 